\title{
Impact of Humorous Advertising on Purchase Decision: In Con- text of Pakistans Telecom Industry
}

\author{
Abbiha Waqar*1 \\ ${ }^{1}$ Lahore School of Economics, Pakistan
}

\begin{abstract}
The purpose of the current study was to examine the impact of humorous advertisement on purchase decision. To the test the hypotheses, Ufone ads were analyzed and compared to other mobile network ads, which are being aired in Pakistans telecom industry. The data were collected from mobile users via survey method. The data were collected from January 2017 to January 2018. The sample size was 127. Data were analyzed using correlation and regression analysis. The findings suggested that humorous advertisement is one of the appeals which breaks the clutter. $90 \%$ of the respondents said that humorous advertisement greatly affects the purchase decision. Hence, Ufones ads are effective. Recommendation for future research would be to study humor in detail; that is dividing the humorous appeal in categories like dark humor, slice of life humor and studying their respective impact on customers purchase decision.
\end{abstract}

\section{Introduction}

The word advertising is derived from a Latin word advertere which means "to turn the mind towards" (Hoang et al., 2013). In today's era, the need of advertising has been emerging and is clearly understood by marketers which is why billions of rupees are spent on advertising annually in Pakistan and one of the major contributors of this is the telecom companies in Pakistan. One of the major reasons for this is the stiff competition among different telecom companies of Pakistan which includes Mobilink, Zong, Ufone, Warid and Telenor. All of these companies are providing very similar services but then they are fighting for the market share very desperately because of the increased competition. Almost $50 \%$ of the spots in electronic channels are being booked by telecom companies of Pakistan.

Different appeals are being used in TVCs but Ufone particularly focuses on humorous appeal in all their TVCs since long period of time. However, no other telecom company relies on humorous appeal for their advertisements. So, this research will be focusing on effectiveness of humorous appeal. The variable for measuring effectiveness will be purchase decision. Humor advertisement on television grabs the attention of viewers. Viewer's in turn enjoy television ads (Ashaduzzaman and Asif-Ur-Rahman, 2011). "The researcher also found that consumer purchase intention also influenced by the span of television commercial (Khuong and Nguyen, 2015).

* Corresponding author.

Email: abbiha233@gmail.com 


\section{Literature Review}

Humorous advertising is basically used for achieving higher sales. Advertiser only spends money if he foresees higher return for that advertisement. To break that clutter various appeals are being used by marketers and one of them which is successful in it is humorous appeal (Hoang et al., 2013). The researchers have found that recall of advertisement is higher if the information is organized in a good way. If there is only humor and information is haphazard, than the message delivery will not be clear and will result in lower recall of that ad. It is also found that message improves memory of products and spokesperson is meaningfully linked together (Krishnan and Chakravarti, 2003). There are various techniques being used by marketers nowadays to tap their target market, but they really need to invest on which type of appeal should be used because not every person is same out there in the market. So for that purpose they really need to assess what majority of the target market likes and dislikes (Hoang et al., 2013).

It is still unclear whether humor in advertising has positive or negative impact on brand recall and purchase decision but still almost $20 \%$ of advertising in America is being done with humorous appeal in it. The major reason for this is that advertisers believe that humor element in ads grabs attention of audience (Bara, 2010). It has been found through research that more attention directly leads to more extensive processing. So humorous ads are processed more in consumers' mind but it cannot be inferred that it leads to positive consumer judgments regarding that brand or product because more extensive processing could also lead to negative feelings in consumers mind. Therefore, it is premature to say that humorous ads lead to more brand recall and positive purchase decision; we also need to understand the evaluative directionality or implication of individuals' cognitive elaborations (Basu and Chattopadhyay, 1990).

Evidence suggests that element of humor in advertisements can also harm the memory for brand claims and products because humor definitely grabs consumers' attention; but on the other hand it also distracts consumer's focus from products and main message of an ad. This means that it is not necessary that humorous advertisement would lead to more sales of the product or service (Strick et al., 2013). Companies should be very careful while establishing brand image in consumers' mind via TVCs because TVCs have a very high impact on purchasing behavior. When it comes to telecom sector, marketers should first focus on delivering the information to users clearly because consumers only switch their mobile connection if the package or call tariffs will suit their needs. So, primary focus of marketers should be delivering the message clearly which could lead to purchase decision (Trivedi, 2013).

Various studies have observed the effectiveness of advertising since couple of decades. The most common measures of advertising effectiveness include brand awareness, attitude of consumer towards the advertisement, recall, click through rate, ad recognition and purchase consideration. The entertainment value is very vital which is analyzed by the level of pleasure and enjoyment which is experienced by audience.

There is no consistent definition for humor which is why there are various terminologies being used to describe humor. In past decade, numerous studies have been conducted to check the advertising effectiveness. Brand awareness, ad recognition, and ad recall, attitude towards the ad and purchase intentions were the common measures of measuring effectiveness. There are various tools through which marketers can communicate and convey their message to the target market. The most important from them for mass communication are sales promotion, advertising and public relations. 


\subsection{Hypotheses}
$H_{1}$ : Celebrity endorsement has positive effect on purchase decision
$\mathrm{H}_{2}$ : Network Quality has positive effect on purchase decision
$\mathrm{H}_{3}$ : Humorous advertisements have positive effect on purchase decision
$H_{4}$ : Attractive Tariff has positive effect on purchase decision
$\mathrm{H}_{5}$ : Brand Image has positive effect on purchase decision

\section{Methodology}

Quantitative research was used for this study. This approach was used to investigate the relationship between variables and to develop hypotheses. Primary data were collected from the mobile users in Pakistan via distributing questionnaires randomly and through online Google forms. Secondary data were collected using different research journals which include JSTOR, Science Direct, etc. The sample size used for this research was 127 respondents and they are mainly mobile users in Pakistan, mostly Ufone mobile network users. Self-administered questionnaire was developed for this research. The questionnaire was designed in this way that it included seventeen closed ended questions. Likert scale and multiple choices are being used in formation of questions. The sampling technique used for this research was simple random sampling. The pretesting was also done by gathering data from 10 respondents in order to reduce the chances of error. So the biasness can be minimized. After pretesting some of the questions were eliminated and the sequences of the questions were changed. In the analysis and results, pretesting sample is not included. The software used for statistical analysis was SPSS. Different tests were performed using this software such as crosstabs, chi-square test etc.

\section{Findings}

The analysis of this study was carried out using statistical software. SPSS is used for reliability and regression analysis.

\subsection{Reliability Analysis}

Reliability can take on values of 0 to 1.0, inclusive. Cronbach's alpha is the measure of scale reliability. The Cronbach alpha's of all the variables/constructs is above the threshold level that is 0.70 . So this indicates that all the variables can meet the criterion of reliability, indicating that all variables are acceptable as shown in Table 1.

\subsection{Regression Analysis}

The regression used for this study is the linear regression model. In this the means of all variables both dependent and independent are used. The adjusted R-squared compares the explanatory power of regression models that contain different numbers of predictors. The R- squared is $42.3 \%$ which indicates goodness of fit for linear regression for this model. But the threshold or cut off point of R-squared is above $50 \%$ to $60 \%$. The p-value indicates the acceptance or rejection of the variables. The p-value is a number between 0 and 1 . If $p$-value is less than or equal to 0.05 , then null hypothesis is rejected, whereas if $\mathrm{p}$-value is more than 0.05 , the null hypothesis 
Table 4.1: Cronbach's Alpha

\begin{tabular}{lc}
\hline Variables & Cronbach's Alpha \\
\hline Celebrity Endorsement & .866 \\
Network Quality & .856 \\
Humorous ad & .842 \\
Brand Image & .862 \\
Call tariff & .824 \\
Purchase Decision & .844 \\
\hline
\end{tabular}

is accepted. So table 2 indicated that for this study the five hypotheses i.e. Celebrity Endorsement, Attractive Tariff, Humorous Advertisement, Network Quality and Brand Image will have significant relationship with purchase decision, and these null hypothesis will be accepted.

Table 4.2: P-Values

\begin{tabular}{lc}
\hline Variables & Significance (P-Value) \\
\hline Celebrity Endorsement & 0.164 \\
Attractive Tariff & 0.679 \\
Network Quality & 0.297 \\
Humorous ad & 0.070 \\
Brand Image & 0.517 \\
\hline
\end{tabular}

$H_{1}$ : Celebrity endorsement has a positive relationship on purchase decision

Nowadays telecom companies are spending so much on celebrity endorsements to get hold on renowned brand ambassadors such as Humaira Anjum by Ufone, Shahid Afridi and Atif Aslam by Warid and Mobilink and Ali Zafar by Telenor. They think that it increases the trust and association with the brand in user's mind which drives their purchase behavior. So this hypothesis was tested in this study and on the basis of significance value of 0.164 which is greater than 0.05 , null hypothesis is accepted.

$\mathrm{H}_{2}$ : Network Quality has a positive relationship on purchase decision

Network quality is one of the core things about any mobile network. This includes mobile coverage, signal strength and amount of congestion on any network. This hypothesis was to test whether mobile users prefer the specific network or not. On the basis of $p$-value of 0.297 which is $>0.05$, hence null hypothesis is accepted, as basic functionality of the mobile sim depends on network quality.

$\mathrm{H}_{3}$ : Humorous advertisements have a positive relationship on purchase decision

The data collected for this study suggests that humorous appeal is surely appreciated by $90 \%$ of the respondents. It quickly grabs attention of the consumer and also people tend to remember humorous ads more than any other. This is surely a success of Ufone as the company aim is not only to attract new customers but to maintain the base of their existing customers. So Ufone 
has been successful in breaking the clutter in the minds of the consumer and positioned itself quite effectively in consumers mind. The results of this study also confirms the success of their advertisements as the p-value is 0.070 , which is greater than 0.05 which is why null hypothesis is accepted, which shows that there is a positive relationship of humorous advertisement with purchase decision.

$\mathrm{H}_{4}$ : Brand Image has a positive relationship on purchase decision

Brand image is basically the perception of brand in user's mind. After conducting this research, there is a certain perception about every mobile company which exists in user's mind. So brand image has a great impact on purchase decision. The p-value of 0.517 which is $>0.05, \mathrm{Null}$ hypothesis is accepted indicating positive relationship of brand image with purchase decision.

$\mathrm{H}_{5}$ : Attractive offers/tariff rates has a positive relationship on purchase decision

Telecom sector in Pakistan is very much price sensitive nowadays. There is fierce competition going on among 5 companies that they all are fighting with each other on basis of few paisas. Pricing department would be on its toes all the time because SEC C customers usually have multiple Sims because of their low prices and they immediately switch their network if they hear some exciting offers or tariff packages announcement. This hypothesis was tested in this study and results showed a positive relationship of attractive tariff offers and purchase decision and p-value came out to be 0.679 which is $>0.05$, hence null hypothesis is accepted.

During survey, respondents were asked to rate humorous ads on basis of their likeness and out of total 127 respondents, 99 said that they like humorous ads. This clearly shows that majority of the mobile phone users prefer watching humorous ads over other type of ads which include animated, informative, celebrity endorsed and emotional appeal ads. Over all appeals used in various ads, majority of the people voted high for humorous ads. This indicates that humor content in ads grabs viewer's attention which helps in better recall.

Table 4.3:

\begin{tabular}{lc}
\hline Hypothesis (Ho) & Results \\
\hline Purchase Decision Celebrity Endorsement & Accepted \\
Purchase Decision Network Quality & Accepted \\
Purchase Decision Humorous advertisement & Accepted \\
Purchase Decision Attractive offers/packages & Accepted \\
Purchase Decision Brand Image & Accepted \\
\hline
\end{tabular}

\section{Discussion}

The findings clearly showed that humorous advertising has a positive relationship on purchase decision but along with advertisements, companies should also be focusing on various other elements such as network quality, coverage, signal strength, SMS packages, lower call tariffs, brand image etc. to compete in the market. The issue which telecom industry is currently facing is that there is not much difference in the services they are providing so they cannot much differentiate in that, so they have to spend a lot on advertisements in order to attract new customers and retain older ones. 
In future, the similar research should be done on national level as this research was mainly focused on Lahore. Customer's attitude, consumer behavior, taste and preferences differ a lot among people of other provinces and rural areas.

\section{Conclusion}

All null hypotheses were accepted. It clearly shows that Ufone's marketing department is rightly spending billions of Rupees per annum on its humorous advertising as their ads recall rate is highest among other telecommunication ads; they have been successful in grabbing mind share of mobile users.

The balance which Ufone achieves between humor content and the message of the ad is just perfect. They key to success of Ufone ads is the way they blend humorous content in their ads, it never felt out of the context in viewers mind. Interflow agency is working hand in hand with Ufone's marketing team and they ensure the execution is perfect in each of their commercial. The humor content enhances the recall of the ad and breaks the clutter in consumer's mind.

Although, switching rate is relatively higher in telecom industry due to various factors which has been studied in this research, but whenever customer switch their network, they definitely consider Ufone as it is the first company which strikes in the mind of potential buyer due to its impressive humorous advertisement and attractive packages. On the other hand existing Ufone customers also enjoy Ufone's humorous advertisement and it strengthens their affiliation and sense of belongingness with Ufone which helps the company in retaining its existing customer base.

\subsection{Limitations, Implications and Future Directions}

During this research, few limitations were present due to which results might be not as much accurate as they could have been if these limitations were not present. Firstly, TVCs could not be incorporated of various telecom companies in questionnaire as Google forms don't have an option of playing videos within questionnaire and respondents feel awkward and time consuming to go to any other website via provided link for watching TVCs and then come back to answer related questions. Secondly, geographic boundaries were another limitation faced during this research. Majority of the respondents were from Lahore. Out of 127 respondents, only $5 \%$ were from outside Lahore, whereas other $95 \%$ resides in Lahore. This was mainly because of lack of resources. There is a chance that results would differ if this research was conducted on a national level. Other than that the humorous appeal could be broken down and interpreted separately.

In future, the similar research should be done on national level as this research was mainly focused on Lahore. Customer's attitude, consumer behavior, taste and preferences differs a lot among people of other provinces and rural areas.

\section{References}

Ashaduzzaman, M. and Asif-Ur-Rahman, S. (2011). Impact of television advertisements on buying pattern of women in dhaka city. European Journal of Business and management, 3(3):16-27.

Bara, C. R. F. (2010). Does humor work in advertising of pharmaceutical products? PhD thesis.

Basu, K. and Chattopadhyay, A. (1990). Humour in advertising: The moderating role of prior brand evaluation.

Hoang, A. T. et al. (2013). Impact of humor in advertising on consumer purchase decision. 
Khuong, M. N. and Nguyen, T. D. (2015). The effects of television commercials on customers purchase intention-a study of milk industry in ho chi minh city, vietnam. Journal of Economics, Business and Management, 3(9):851-857.

Krishnan, H. S. and Chakravarti, D. (2003). A process analysis of the effects of humorous advertising executions on brand claims memory. Journal of consumer psychology, 13(3):230-245.
Strick, M., Holland, R. W., van Baaren, R. B., Knippenberg, A. v., and Dijksterhuis, A. (2013). Humour in advertising: An associative processing model. European Review of Social Psychology, 24(1):32-69.

Trivedi, S. (2013). Would brand recall impact the customer buying behavior of mobiles. Global Journal of Management and Business Studies, 3(10):1129-1134. 